\title{
Adoption of Children With Disabilities: A Study With Adoptive Parents ${ }^{1}$
}

\author{
Gisele De Mozzi \\ Universidade Federal de Santa Catarina, \\ Florianópolis-SC, Brazil
}

\author{
Adriano Henrique Nuernberg \\ Universidade Federal de Santa Catarina, \\ Florianópolis-SC, Brazil
}

\begin{abstract}
Taking into consideration the supremacy of a child's profile often chosen by adoptive parents, this study aimed to understand the adoption of children with disabilities from the perspective of adoptive parents who have experienced this practice. The participants were eleven adoptive families of disabled children, all of whom had knowledge about the health conditions of the adoptive children at the time of adoption. The instruments used were a semi-structured interview and a sociodemographic questionnaire. A content analysis of the results enabled an understanding of the influence of conceptions about disabilities on the formal adoption process, the construction of parenting through the practices of care, and the influence of care specificities for a disabled child on adoption processes. Finally, it can be concluded that the children's disabled condition is a constituent element in the adoption of these children, affecting both the legal processes and the experience of the adoptive families.
\end{abstract}

Keywords: adoption (child), adopted children, caregivers, family relations

\section{Adoção de Crianças com Deficiência: Um Estudo com Pais e Mães Adotantes}

\begin{abstract}
Resumo: Dada a supremacia de um perfil de criança adotiva frequentemente escolhido pelos pretendentes, objetivou-se compreender a adoção de crianças com deficiência na perspectiva dos pais adotivos que vivenciaram esta prática. Fizeram parte da pesquisa onze famílias adotantes de crianças com deficiência, que tinham conhecimento sobre a condição física e de saúde da criança no momento da adoção. Os instrumentos utilizados foram: entrevista semiestruturada e questionário sociodemográfico. A análise de conteúdo dos resultados permite problematizar a influência das concepções de deficiência sobre o processo formal de adoção, a construção da parentalidade por meio das práticas de cuidado e as influências das especificidades do cuidado de crianças com deficiência sobre os processos de adoção. Concluiu-se que a condição de deficiência é um elemento constituinte da experiência de adoção dessas crianças, operando tanto no processo judicial quanto na vivência das famílias adotantes.
\end{abstract}

Palavras-chave: adoção (criança), crianças adotivas, cuidadores, relações familiares

\section{Adopción de Niños con Discapacidad: Un Estudio de los Padres y Madres Adoptivos}

\begin{abstract}
Resumen: Dada la supremacía de un perfil de niño adoptivo frecuentemente escogido por los pretendientes, se tuvo como objetivo comprender la adopción de niños con deficiencia en la perspectiva de los padres adoptivos que vivieron esta práctica. Once familias adoptantes de niños con deficiencia, que tenían conocimiento sobre la condición física y salud del niño en el momento de la adopción, participaron de una entrevista semiestructurada y cuestionario sociodemográfico. El análisis de contenido permite problematizar la influencia de las concepciones de deficiencia en el proceso de adopción formal, la construcción de la parentalidad a través de las prácticas de cuidado y las influencias de las especificidades del cuidado de niños con deficiencia sobre los procesos de adopción. Se concluyó que la condición de deficiencia es un elemento constituyente de la experiencia de adopción de estos niños, operando tanto en el proceso judicial cuanto en la vivencia de las familias adoptantes.
\end{abstract}

Palabras clave: adopción (niño), niños adoptivos, cuidadores, relaciones familiares

One of the leading contemporary findings with respect to Brazilian adoption is the paradox between the number of applicants for adoption and the number of children registered: for each child, about five applicants are waiting in line, according to information released by the National Register of Adoption (CNA). This disparity appears to be

\footnotetext{
${ }^{1}$ Article derived from the master's thesis of the first author under the supervision of the second, defended in 2015, in the Graduate Psychology Program at the Universidade Federal de Santa Catarina.

${ }^{2}$ Correspondence address:

Gisele De Mozzi. Rua Santos Saraiva, 469, apto 101A, Estreito. CEP 88070-

10. Florianópoli-SC, Brazil. E-mail: gisele.dmozzi@gmail.com
}

justified, primarily, by the profile of the child required by the applicants: white, newborn and healthy (Amin \& Menandro, 2007; Fonsêca, Santos \& Dias, 2009; Silveira, 2005). Not all adoptions in the Brazilian context may have been accounted for by the CNA, given the occurrence of "ready adoptions", when there is a legal form of adoption that has been previously defined (Mariano \& Rossetti-Ferreira, 2008; RossettiFerreira et al., 2012). In the Brazilian legislation, with the establishment of Law No. 12,010 (2009) (New National Adoption Law), greater incentive was provided to promote policies and programs to stimulate inter-racial adoption, the adoption of older children, adoption of sibling groups, and even the adoption of children with special health care 
needs or disabilities, characteristics known internationally as special needs (Glidden, 1991; Rosenthal, 1993).

Based on the report released for public consultation by the National Adoption Register (2015), it has been verified that approximately $24.73 \%$ of these children have some disability or illness, classified as: treatable disease, untreatable illness, physical disability, mental disability or HIV. Information regarding the acceptance of applicants with these characteristics is not released. However, this percentage indicates the need to expand research on the adoption of children with bodily and/ or health conditions that do not seem to correspond with the profile often chosen by applicants for adoption.

With regard to scientific production, a variety of possibilities for research and contemporary questioning about adoption can be found, such as: adoptive homosexual parenting (Amazonas, Veríssimo, \& Lourenço, 2013; Cecílio, ScorsoliniComin, \& Santos, 2013; Pereira, Torres, Falcão, \& Pereira, 2013), the new National Adoption Law (Oliveira \& Schwartz, 2013; Silva \& Arpini, 2013), the institutionalization of children awaiting adoption (Cavalcante, Costa, \& Magalhães, 2012), among others. Regarding the investigation on the condition of disability, there is currently tension between the different theoretical approaches, namely: the biomedical, social and biopsychosocial. These three principle perspectives related to the field of Disability Studies reflect disagreements and tensions experienced by persons with disabilities and their families, and have consequences for public policy, rehabilitation practices, actions and conducted research.

The traditional medical focus considers that the limitation on body function or structure causes disability or disadvantage relative to normal patterns (Barnes, 2009; Diniz, 2007). Based on this perspective, the disabled body is transformed into the subject of medical interventions and rehabilitation practices intended to cure, normalize or eradicate the body's limitation, adapting to the "damaged body" (Diniz, 2003; Martins, Fontes, Hespanha, \& Berg, 2012), which carries an emotional and economic burden both for the family and the state and creates barriers for people with disabilities and their families (Barnes, 2009).

The biopsychosocial model attempts to integrate the medical and social perspectives by means of a more systemic approach, in which both the dimension of the body as well as the environmental barriers are contemplated (Farias \& Buchalla, 2005). The biopsychosocial perspective provides the potential for including the family of disabled people in the care, assessments and interventions, going beyond the medical care to include a set of services, measures and support activities and care for people with disabilities and their families (Barnes, 2009).

The social model is the theoretical choice that conducts the analysis of the adoption phenomenon of children with disabilities in this study. Its emergence was guided by the fight against the invisibility, inequality and oppression of disability experiences and, in this sense, represents a change in the paradigm from the hegemonic medical model. Without neglecting the importance of biomedical knowledge for the well-being of individuals with disabilities, the social model understands disability as the product of a body's interaction with impairments of a physical, sensory or intellectual nature, in an environment that does not accept the body's variation (Diniz, 2003, 2007). It is the result of social arrangements that are insensitive to human diversity (Barnes, 2009; Diniz, 2007), the result of a society that does not recognize individuals with biological impediments, which are considered unacceptable because of normalized and exclusionary social standards (Barnes, 2009).

With the emergence of the social model, it is possible to include new discussions to the field of Disability Studies, such as the experiences of women with bodily impairments and female caregivers of disabled people and the transversality of oppression by the disability with other categories such as race / ethnicity, gender, generation, among others (Diniz, 2003). From the perspective of the feminist ethic of disability and caring, comprehension is promoted that, in addition to the disability, the care and interdependence are also constituents and are inherent to the human condition (Diniz, 2003; Kittay, Jennings, \& Wasunna, 2005; Mello \& Nuernberg, 2012).

From the proposal of the social model, the experience of having a disabled child is an important element of the parents' identity (Solomon, 2012), who also live an experience of disability, because, when they exercise the care and the education of their children, they confront barriers derived from environments which are insensitive to human physical and functional variation. Recognizing the diversity of family organizations, showing the experiences of each family as positive and valuing their narratives, without ignoring the possible impact of disabilities, are trends in contemporary research about family and disability (Ferguson, 2000).

The methodological choice for the research with adoptive fathers and mothers is guided by the need to integrate people with disability experience into policy discussions, programs and studies about this theme (Baglieri, Valle, Connor, \& Gallagher, 2011; Martins et al., 2012), which is recommended by the Convention on the Rights of Persons with Disabilities (Legislative Decree No. 186, 2008). The inclusion of male and female caregivers in proposals on disability studies finds support also in authors such as Ferguson (2000), and in feminist contributions to the social model (Diniz, 2007).

Despite the diversity of publications found that dealt with adoption and disability, only the article by Fonsêca et al. (2009) specifically talked about the adoption of children with disabilities within the Brazilian context. The authors developed a thematic analysis based on interviews with adoptive fathers and mothers. As the main results of their work, Fonsêca et al. highlighted the parents' commitment to their children, the prejudice experienced, and the demand for social support for adoptive parents. They concluded that, despite the difficulties found, the adoption of children with disabilities has occurred satisfactorily and can provide satisfaction to the adopters.

The relevance and diversity of possibilities on research about adoption and disabilities, the recent government initiatives, and the prevalence of the child's profile most often chosen by applicants reaffirm the need for further studies at the center of these issues. Thus, research about the adoption of children with disabilities can contribute to reflections on 
adoption, as a form of exercising parenthood, expanding the concept of family and the recognition of different forms of family organization, still favoring the understanding of disability as a possibility of expression of human diversity.

This study intends to present the results of research conducted with adoptive families of children with disabilities, which aimed to identify characteristics of the adoption process of these children, from the perception of parents who lived this experience. We attempted to understand the stories and experiences of adoptive parenting of these families, identify sociodemographic variables that characterized them, and identify possible barriers and facilitating factors for adoptions. In other words, given the supremacy of a foster child's profile often chosen by applicants, this study aimed to understand the adoption of children with disabilities from the perspective of adoptive parents who have experienced this practice.

\section{Method}

\section{Participants}

The research was conducted with eleven families in southern Brazil, which had one adopted child within their family, with any physical, sensory or intellectual disability. The definitions of disability established by the United Nations Convention about the Rights of Persons with Disabilities (Legislative Decree No. 186, 2008) were adopted. As a requirement for participation in the study, adoptive parents were included if they had completed the adoption process and knew about the child's disability at the time they decided to adopt, which means less risk of frustration due to the diagnosis and less probability of return of the adopted child, as noted by Glidden (1991) and Rosenthal (1993). The time of adoption, ranging from one to 16 years, was not considered as an inclusion criterion for the research.

Four fathers and 12 mothers were interviewed, considering the diverse possibilities of contemporary family organization: eight nuclear families consisting of a father and mother; two single parent families composed of single mothers, and one homosexual family, consisting of two women. In four of the eight families composed of a father and mother, the interview was conducted only with the mothers; in two of them this was the option of the family; for the other two families, it was due to scheduled times for interview that were characterized as a limitation of the study. The interviews with fathers and mothers of the same family were performed together.

Table 1 presents information that characterizes the families participating in the survey. Regarding occupation, participants described different activities, especially in the area of education: there were four teachers and one pedagogue. The educational level of most respondents was graduate school. The family monthly average salary was R\$ 9,545 , and all the families lived in their own houses. In two of the three families who adopted two children, both of them are disabled children.

Table 1

Sociodemographic Characteristics of the Families Participating in the Research

\begin{tabular}{|c|c|c|c|c|c|c|}
\hline Participants & Age & Marital status & Biological children & Adoptive children & Body condition & Age when adopted \\
\hline Mother 1 & 54 & \multirow{2}{*}{ Married } & No & \multirow{2}{*}{2} & Blindness & 16 months \\
\hline Father 1 & 49 & & No & & Autism & 16 months \\
\hline Mother 2 & 44 & \multirow{2}{*}{ Married } & No & \multirow{2}{*}{2} & & 13 months \\
\hline Father 2 & 44 & & No & & Cerebral palsy & 5 months \\
\hline Mother 3 & 48 & Married & Yes & 1 & Autism & 2 years \& 6 months \\
\hline Mother 4 & 59 & \multirow{2}{*}{ Married } & Yes & \multirow{2}{*}{2} & Physical disability & 1 year \& 10 months \\
\hline Father 4 & 62 & & Yes & & Cerebral palsy & 10 months \\
\hline Mother 5a & 46 & \multirow{2}{*}{ Domestic partner } & No & \multirow[b]{2}{*}{1} & \multirow{2}{*}{ Cerebral palsy } & \multirow{2}{*}{2 years \& 8 months } \\
\hline Mother 5b & 48 & & No & & & \\
\hline Mother 6 & 31 & Married & Yes & 1 & Physical disability & 14 months \\
\hline Mother 7 & 60 & Domestic partner & No & 1 & $\begin{array}{l}\text { Intellectual dis- } \\
\text { ability }\end{array}$ & 3 months \\
\hline Mother 8 & 62 & Married & Yes & 1 & Physical disability & 3 years \\
\hline Mother 9 & 33 & \multirow{2}{*}{ Married } & Yes & \multirow{2}{*}{1} & \multirow{2}{*}{ Down Syndrome } & \multirow{2}{*}{15 days } \\
\hline Father 9 & 36 & & Yes & & & \\
\hline Mother 10 & 32 & Single & No & 1 & Down Syndrome & 5 months \\
\hline Mother 11 & 52 & Single & No & 1 & Deafness & 21 months \\
\hline
\end{tabular}




\section{Instruments}

Sociodemographic questionnaire. The intention was to gather information about the fathers and mothers participating in the research and their biological or adoptive children. Given the importance of including disability as a category of analysis in psychology studies (Gesser, Nuernberg, \& Toneli, 2012; Mello \& Nuernberg, 2012), and the proposal for mainstreaming disability with other analytical categories (Diniz, 2007), it was fundamental to know the sociodemographic characteristics of the interviewed families and include information on age, education, profession, salary, and physical condition of the adopted children.

Semi-structured interview. Instigated from guiding principles (Minayo, 2009), this interview format favors the intersubjective relationship between the researcher and the respondent, and allows an understanding of the meanings, motivations and opinions of fathers and mothers about the experience of adopting children with disabilities. A semistructured interview meets exploratory purposes, allows the detailing of more complex and sensitive issues and the understanding of a particular reality in its complexity (Fraser $\&$ Gondim, 2004). The guiding principles were: the reasons why these parents exercised parenting through adoption, the adoption process, the establishment of a bond between the adoptive parents and the child, possible barriers or prejudice experienced due to adoption and/or by the disability.

\section{Procedure}

Data collection. The participating families in the survey were accessed through the activation of the contact network of the authors of this text, using the snowball sampling technique (Heckathorn, 2011). The interviews were conducted at the home or workplace of the participants. All interviews were recorded and transcribed with the consent of the participants. A copy of the transcripted interviews was sent to each participant by email, so that possible changes could be made.

Data analysis. The analysis of the material produced was conducted using thematic content analysis (Bardin, 1977/2010). The recurrence of issues that crossed the interviews was used as a criteria for separating the text into thematic indicators. These indicators were related to the research objectives and guiding principles of the interview, and allowed for the construction of meaning units that, although organized into different categories, were interconnected. They were: previous family experiences and motivations for adoption, disability concepts and their influences on the adoption process, construction of family bonds and care practices in adoptive families of children with disabilities.

\section{Ethical Considerations}

This study was approved by the Ethics Committee for Research with Human Beings (CEPSH) of the Universidade Federal de Santa Catarina, Protocol no. 746552, on August 11, 2014 (CAEE: 32931714.1.0000.0121). In order to ensure the ethical principles recommended by Resolution 466/12 of the National Health Council, the Free and Informed Consent Form was signed by all participants. The families were sequentially coded by number one to eleven, to prevent identification, and each member of the family received the same number, preceded by parentage (father or mother).

\section{Results and Discussion}

\section{Preliminary Family Experiences and Motivations for Adoption}

The bonding process with adopted children and the recognition of adoption as one of the possibilities foe exercisind parenthood seemed to be a characteristic of the principle motivations for the effectiveness of adoptions experienced by the fathers and mothers interviewed. Seven families knew the children before any registration occurred for the adoption process, and from this experience decided to exercise adoptive parenting. The reasons why applicants adopt children with disabilities do not differ from the other adoptive families, such as: always having thought about adopting, the desire for companionship in their old age, the desire to be a mother, and the choice to be a single mother (Otuka, Scorsolini-Comin, \& Santos, 2009). However, insufficient information, financial resources (Rosenthal, 1993) and psychological preparation to assume special care can influence applicants to avoid adopting children with disabilities (Fonsêca et al., 2009).

Another aspect that favored the adoption of a disabled child was prior family experiences with the condition of disability. It is noteworthy that, of the 16 participants, six mothers reported having worked or currently working in the education field, which seemed to evidence their knowledge about national policy on inclusive education. The professional career of these mothers and their experiences with disability, as the case of a mother whose biological son was disabled, were characterized as factors that contributed to a nuanced understanding about the child's physical condition and the recognition of disability as one the components of the child's identity, transversal to other characteristics such as gender, age, race/ethnicity, among others. As also noted by Glidden (1991), previous experiences with the condition of disability were therefore determining factors in the process of adopting children with disabilities.

\section{Conceptions of Disability and Their Influences on the Formal Adoption Process}

Narratives are common from adoptive parents, applicants for adoption and professionals working in the area, about the waiting time required for adoption to occur, which usually takes two to five years from the time the applicants register (Amin \& Menandro, 2007). The experiences described by the participants of this study showed, however, the agility they experienced in the completion of adoptions, as well as less time waiting: three months to 18 months or so: "In four, four months for the children to be at home with us" (Mother 1); 
"Six to nine months because it was not, it did not take more than nine months to finalize his adoption" (Mother 5b).

For families who knew the children prior to registration for the adoption, there was no waiting time for the arrival of the child, only the time elapsed to formalize the adoption, showing agility in the processes. However, even for those families that started the adoption process through registration, the waiting period was not more than a year and a half; lower than that reported in other studies (Amin \& Menandro, 2007). Knowing the child and previous contact with her appeared to be fundamental to both the decision to adopt and the agility of adoptions experienced by families interviewed. Despite the shorter time to complete the adoption, this agility did not seem to exclude the component steps of the formal process of adoption, since the participants reported having the legal proceedings to qualify for adoption, the psychosocial interviews, and adoption support group participation.

The fathers and mothers interviewed also reported the refusal of other potential adopters who occupied the top positions on the waiting list to accept the available children, which also seems to have contributed to the fact that the research participants were contacted and had their requests for adoption streamlined. The statement of Mother 10 is representative of this situation:

Five families were called before me, who had said they wanted, could have a disabled child, one was traveling to Europe, the others did not want the child ... and finally! The five families before me ... did not want.

The experiences reported by respondents allow an understanding of the double role that the disability category seems to occupy in the adoption processes: on the one hand, it complicates the adoption of children whose bodily conditions do not meet the characteristics chosen and accepted by most applicants. This refusal appears linked to the medical model of understanding the disability, which perceives it as an illness, a personal tragedy, as an injured body (Barnes, 2009; Diniz, 2003; Martins et al., 2012), therefore, he cannot be the ideal of child sought by the adoptive parents. On the other hand, when there is an active search for potential parents, the disability seems to speed up adoption processes involving children in this condition, reducing the waiting time to become adoptive fathers and mothers.

The recognition of the exclusion of some characteristics of the preference list of applicants for adoption (Amin \& Menandro, 2007; Fonsêca et al., 2009; Silveira, 2005), led to the recent formulation of Law No. 12,955 (2014), which gives priority for the proceedings of adoption processes for children with disabilities or chronic illness, and part of the understanding that greater agility in the adoption process may favor the development of these children. Thus, although for some adopters, disability and specificities of care and differentiated service resulting from the physical and child health conditions imply a refusal in their acceptance of a child, for adoptive fathers and mothers in this research, this condition was precisely what seemed to speed up and facilitate the adoption process, in addition to the frequency and urgency with which the treatments needed to be performed.
The different ways of understanding the disability reflect, therefore, the different approaches and practices directed at the families with experiences of disability (Barnes, 2009; Ferguson, 2000), being able to influence judicial decisions and legislative strategy which streamline the adoption process for these children. Similarly, families also reproduce understanding and discourse on disability, sometimes understanding it as a disease that needs to be cured and treated (medical model), or considering the body condition of the child as one of the constituent features of his identity and as a variation of human diversity that needs to be cultivated and respected (social model; Ortega, 2009).

Regarding the age of the children at the time they were adopted, the adoption of older children was observed with the least frequency: all children adopted were younger than three years old, of which 11 were less than or equal to one year old, corresponding to $78.57 \%$ of children adopted. This percentage is similar to that evidenced by Mariano and Rossetti-Ferreira (2008), whose research showed that $70 \%$ of children adopted were under one year of age. Based on the concepts of interdependence and care defended by the social model (Diniz, 2003; Kittay et al., 2005; Mello \& Nuernberg, 2012), it is possible to understand how a greater dependence on special care required by the child with disabilities can contribute to speeding up the adoption of these children.

\section{Construction of the Family Bond in the Adoption Process and the Care Practices}

Based on the results of this research, the adoption of children with disabilities may not necessarily have been a specific choice delineated prior to it happening, but the product of a bonding process between the adoptive fathers and mothers and the adopted child. This bonding process, in turn, was influenced by the child's active role and the care practices exercised by the interviewed fathers and mothers.

Some fathers and mothers reported the practice known as affective sponsorship (Sousa \& Paravidini, 2011), conducted among volunteers who bring the institutionalized children to their home for a short period of time, especially on weekends and in the end of year for holiday season, a practice reported by four families. These fathers and mothers seem to have developed the foster parenting from the care exercised with the children on the weekends, which was essential, even for the decision to adopt them. Regarding the moment they began to feel they are parents of their adopted children, Family 1 said that it was during the holiday season, highlighting the care practices performed in this period, characterized by "changing diapers" (Father 1) and "total dedication with them" (Mother 1).

From the interactions established with the child in the first contacts with her, in addition to the care practices, the adoptive parents also described looks, touches, caresses, smiles and other experiences, marked by reciprocity and the active role of the child: "Then I got so I passed my hand on her little head and down her little body and when I ran my hand on her back, she smiled. 'She is mine!', I said" (Mother 7). The contemporary perspectives on attachment allow the 
statement that both the individual characteristics of caregivers and their sensitivity to meet the needs of the child, for the child's identity characteristics and their ability to signal to caregivers about their needs and desires, are decisive in the construction process of the bond between caregivers and children (Brum \& Schermann, 2004; Pontes, Silva, Garotti, \& Magalhães, 2007).

The fathers and mothers interviewed also reported statements of people to whom they were close and/or who they know that, faced with the possibility of adoption, recognized, valued and legitimized their roles as fathers and mothers. This social recognition of motherhood/fatherhood is expressed in the statement of Mother 3, when she said that, visiting her daughter at the host institution, the local professionals named her as the mother: "So then, I took her there in the shelter and everyone said 'look who is here, [name of the adoptive daughter]!' Mom has come!" (Mother 3).

Some experiences described by the adopters made explicit the need for special care that some of these children with disabilities may require. The participants mentioned financial resources, time availability, assistive technologies, monitoring with different professionals such as physicians, physiotherapists, speech therapists, among others, as also observed by Nunes and Dupas (2011), with regard to Down syndrome. However, the additional needs of care are not applicable and generalizable to all adoptive families of children with disabilities, since our survey participants showed that the bodily condition of the children does not always imply a differentiation of care.

They do not think that this is a child, that sometimes people say, 'Oh, I do not have time to care' or 'I will not have money'. Sometimes you have to evaluate the disability. . . Sometimes it is not a financial issue that will involve the disability, right. It is your love, your dedication there. . . I do not have to stop my life, to be with her in a hospital, because that's what people think of disability. (Mother 6)

Although the reflections raised by the narrative of this mother are fundamental to understanding the naturalization of care and additional resources required by children with disabilities, some bodily conditions imply higher financial expenses and a greater investment of time and care by the family (Glidden, 1991). Some bodily conditions described by other participants were associated with health conditions that required recurrent hospitalizations, as described by Mother 10: "Then, well, it was 20 days in the hospital and ten days at home".

The financial resources, in turn, are referred to on a recurring basis in the statements of the interviewed fathers and mothers, indicating additional expenses for the guarantee of care and treatment and for the promotion of health conditions linked to the body and/or functioning of the child, which was also observed by Glidden (1991) and Rosenthal (1993). This encourages some parents to question the possibility of such additional financial expenses are characterized as one of the reasons why other applicants do not accept to adopt children with disabilities: "A special child triples this financial problem. So, perhaps, this is one of the reasons that people do not want to take them!" (Mother 4).
The fathers and mothers interviewed showed, in their narratives, the activation of a public and private support network, which is favorable to ensuring care for foster families (Fonsêca et al., 2009; Rosenthal, 1993). In contrast, some fathers and mothers revealed the complexity involved in the search for a truly inclusive school and the difficulties in finding people who could help them with the care of children, whether they are members of the social network or professionals hired for this purpose.

When the family is eligible as the only healthy development space (Rossetti-Ferreira et al., 2012), the accountability for overcoming the barriers imposed on the children with disabilities rests solely on their fathers and mothers. Through a moral and guilt-inducing approach, the family is sometimes responsible for the disability that the child experiences, for the public spending, for dependency on care, for the rehabilitation and social inclusion (Barnes, 2009) and their knowledge and forms of care are delegitimized. Seen as harmful to professional intervention, the family also becomes a passive object of intervention, with the intention of regaining a state of equilibrium, as it is perceived as dysfunctional due to the disability (Ferguson, 2000).

The understanding of bonding as a construct, embedded in a dynamic network of relationships, allows for the consideration that the formation of emotional bonds is also influenced by contextual elements and cultural particularities regarding care practices (Pontes et al., 2007; Rossetti-Ferreira et al., 2012). Described by respondents as key elements of routine care, the school and social support network can be characterized as privileged places to promote interdependence and care (Diniz, 2003; Guimarães, 2010; Kittay et al., 2005). This sharing of care practices with the social network of support and the school can enhance the guarantee of appropriate care that meets the specific bodily condition of the child, and at the same time guarantees the rights, on an equal basis and without discrimination, as recommended by the Convention on the Rights of Persons with Disabilities (Legislative Decree No. 186, 2008).

It is understood that adoptive parenting, for the fathers and mothers participating in the research, is constituted by: the lived experience of care, the social recognition of fatherhood/motherhood, and the active role of the child in the process of building of emotional bonds. It is also possible to imagine the greater need for care required by a child with disabilities could contribute to the establishment of a more intense, rapid and definitive connection.

The understanding of disability, on the part of the medical model, for which any bodily change is perceived as a disease that needs to be cured and treated (Barnes, 2009; Diniz, 2007), and the generalization of additional care needs and resources for each and every bodily change, seem to be reflected in the choices of applicants for adoption. In addition, the bias of valuing homogeneity (Silveira, 2005; Solomon, 2012), in the child adoption processes, and the rejection of bodily variation, restrict the possibility of living with the differences and the exercise of otherness (Silveira, 2005).

Incorporating the precepts of the social model of disability 
is configured as a challenge, which allows us to understand the need for interdependence and care to be shared, as inherent to the human condition and understood as a matter of justice and human rights (Guimarães, 2010; Kittay et al., 2005; Mello \& Nuernberg, 2012). This perspective can contribute to the recognition of care practices that go beyond the private sphere and perfomance of caring, charitable, segregationist, and exclusionary, which historically delineate the care addressed to people with disabilities (Diniz, 2007). Moreover, it can legitimize the different strategies adopted by families with experience in disability to provide care for its members.

As limitations and difficulties of this research, the small sample size and the homogenization of the sociodemographic characteristics of research participants are indiated, along with bias inherent in the snowball sampling technique, which prevent generalization of the results. The participation of a smaller number of men/fathers is also characterized as a limitation of the study, and deserves higher investments in future work. Achieving factors of a subjective nature, as evidenced in religious issues, in turn, was one of the difficulties experienced in the interviews.

Despite the difficulties and limitations, the research conducted brings contributions from an exploratory perspective. With this study, we can conclude that the condition of disability is characterized as a constituent element of the adoption experience, which acts both on the legal proceedings and on the experience of adoptive families. The adoption process described by fathers and mothers interviewed showed the construction of adoptive parenting through a mosaic of experiences and motivations, the social recognition of fatherhood/motherhood, and the child's active role in the bonding process.

The adoption of children with disabilities is not characterized, therefore, only by charitable or religious relationships, or motivated by infertility of the adoptive fathers and mothers, perspectives linked to the medical model which understands disability as a personal tragedy. Based on the social model and the results of this research, it is possible to understand that the adoption of children with disabilities was constructed from concrete experiences of emotional formation of bonds and recognition of disability as a constituent characteristic of the child's identity. The condition of disability operates and intensifies the construction of emotional bonds between adopters and children adopted, due to increased demand for care, depending on the physical and attitudinal barriers that these children experience.

Recent legislative proposals, social and media visibility on the adoption of children with disabilities, associated with the results found in this study, represent an investigative potential that needs scientific deepening in the country. It is expected, therefore, that the reflections raised by the text might suggest new dialogues, research, discussions, performances and interventions directed toward families with disability experiences, especially adoptive fathers and mothers of children with disabilities.

As consequences of this research, the specificities of the different forms of family organization in adopting children with disabilities and also the peculiarities of the bodily condition of children can be investigated. Investigation of possible links between parental beliefs and values and motivations for adopting children with disabilities, and the analysis of the implications of the implementation of Law No. 12,955 (2014), are suggested. Regarding the specificities of care and resources required by persons with disabilities, efforts could be devoted to investigate the biological families who offer their children with disabilities for adoption, as well as about the aging of caregivers. Proposal for future research are characterized by the need for further studies on the care and the development of attachment in adoption.

\section{References}

Amazonas, M. C. L. A., Veríssimo, H. V., \& Lourenço, G. O. (2013). Adoption of children by gay people. Psicologia \& Sociedade, 25(3), 631-641. doi:10.1590/S010271822013000300017

Amim, I. D., \& Menandro, P. R. M. (2007). Preferências por características do futuro filho adotivo manifestadas por pretendentes à adoção [Preferred characteristics of future adopted children manifested by prospective adoptive parents]. Interação em Psicologia, 11(2), 241-252. doi:10.5380/psi.v11i2.7653

Baglieri, S., Valle, J. W., Connor, D. J., \& Gallagher, D. J. (2011). Disability studies in education: The need for a plurality of perspectives on disability. Remedial and Special Education, 32(4), 267-278. doi:10.1177/0741932510362200

Bardin, L. (2010). Análise de conteúdo [Content analysis] (L. A. Reto \& A. Pinheiro, Trans.). Lisboa, Portugal: Edições 70. (Original work published 1977)

Barnes, C. (2009). Un chiste malo: Rehabilitar a las personas con discapacidad en una sociedad que discapacita [A bad joke: Rehabilitating the disabled people in a society that disables]. In P. Brogna (Ed.), Visiones y revisiones de la discapacidad [Visions and revisions of disability] (pp. 101-122). México, DF: FCE.

Brum, E. H. M., \& Schermann, L. (2004). Vínculos iniciais e desenvolvimento infantil: Abordagem teórica em situação de nascimento de risco [Early relations and infant development: Theoretical approach in risk birth situation]. Ciência \& Saúde Coletiva, 9(2), 457-467. doi:10.1590/S1413-81232004000200021

Cavalcante, L. I. C., Costa, L. N., \& Magalhães, C. M. C. (2012). Caretaking behavior among siblings in children's shelters. Psicologia: Reflexão e Crítica, 25(1), 165-173. doi:10.1590/S0102-79722012000100020

Cecílio, M. S., Scorsolini-Comin, F., \& Santos, M. A. (2013). Produção científica sobre adoção por casais homossexuais no contexto brasileiro [Scientific production on adoption by gay couples in Brazilian context]. Estudos de Psicologia (Natal), 18(3), 507-516. doi:10.1590/S1413294X2013000300011

Conselho Nacional de Justiça. Cadastro Nacional de Adoção. (2015). Relatório estatístico [Statistical report]. Retrieved from http://www.cnj.jus.br/cna/publico 
Decreto Legislativo No. 186. (2008, 9 de julho). Aprova o texto da Convenção sobre os Direitos das Pessoas com Deficiência e de seu Protocolo Facultativo, assinados em Nova Iorque, em 30 de março de 2007 [Approves the text of the Convention on the Rights of Disabled People and its Optional Protocol, signed in New York on March 30, 2007]. Brasília, DF: Senado Federal.

Diniz, D. (2003). Modelo social da deficiência: A crítica feminista [Social model of disability: The feminist critic]. SérieAnis, 28, 1-8. Retrieved from http:// repositorio.unb.br/bitstream/10482/15250/1/ARTIGO_ ModeloSocialDeficiencia.pdf

Diniz, D. (2007). O que é deficiência? [What is disability?]. São Paulo, SP: Brasiliense.

Farias, N., \& Buchalla, C. M. (2005). A classificação internacional de funcionalidade, incapacidade e saúde da organização mundial da saúde: Conceitos, usos e perspectivas [The international classification of functioning, disability and health: Concepts, uses and perspectives]. Revista Brasileira de Epidemiologia, 8(2), 187-193. doi:10.1590/S1415-790X2005000200011

Ferguson, P. M. (2000). Mapping the family: Disability studies and the exploration of parental response to disability. In G. L. Albrecht, K. D. Seelman, \& M. Bury (Eds.), Handbook of disability studies (pp. 373-395). Thousand Oaks, CA: Sage.

Fonsêca, C. M. S. M. S., Santos, C. P., \& Dias, C. M. S. B. (2009). A adoção de crianças com necessidades especiais na perspectiva dos pais adotivos [The adoption of children with special needs in the perspective of foster parents]. Paidéia (Ribeirão Preto), 19(44), 303-311. doi:10.1590/ S0103-863X2009000300004

Fraser, M. T. D., \& Gondim, S. M. G. (2004). Da fala do outro ao texto negociado: Discussões sobre a entrevista na pesquisa qualitativa [From the speech of the other to the negotiated text: Discussions about the interview in the qualitative research]. Paidéia (Ribeirão Preto), 14(28), 139-152. doi:10.1590/S0103-863X2004000200004

Gesser, M., Nuernberg, A. H., \& Toneli, M. J. F. (2012). A contribuição do modelo social da deficiência à psicologia social [The contribution of the social model of disability to the social psychology]. Psicologia \& Sociedade, 24(3), 557-566. doi:10.1590/S0102-71822012000300009

Glidden, L. M. (1991). Adopted children with developmental disabilities: Post-placement family functioning. Children and Youth Services Review, 13(5-6), 363-377. doi:10.1016/0190-7409(91)90026-E

Guimarães, R. (2010). Gênero e deficiência: Um estudo sobre as relações de cuidado [Gender and disability: A study of the relations of care]. In D. Diniz \& W. Santos (Orgs.), Deficiência e discriminação [Disability and discrimination] (pp. 197-228). Brasília, DF: Letras Livres/EdUnB.

Heckathorn, D. D. (2011). Snowball versus respondentdriven sampling. Sociological Methodology, 41(1), 355366. doi:10.1111/j.1467-9531.2011.01244.x

Kittay, E. F., Jennings, B., \& Wasunna, A. A. (2005).
Dependency, difference and the global ethic of longterm care. The Journal of Political Philosophy, 13(4), 443-469. doi:10.1111/j.1467-9760.2005.00232.x

Lei No. 12.010, de 3 de agosto de 2009. (2009, 4 de agosto). Dispõe sobre adoção; altera as Leis Nos. 8.069, de 13 de julho de 1990 - Estatuto da Criança e do Adolescente, 8.560, de 29 de dezembro de 1992; revoga dispositivos da Lei No. 10.406, de 10 de janeiro de 2002 - Código Civil, e da Consolidação das Leis do Trabalho - CLT, aprovada pelo Decreto-Lei No. 5.452, de 1ํo de maio de 1943; e dá outras providências. Diário Oficial da União, seção 1.

Lei No. 12.955, de 5 de fevereiro de 2014. (2014, 6 de fevereiro). Acrescenta $\S 9^{\circ}$ ao art. 47 da Lei No. 8.069, de 13 de julho de 1990 (Estatuto da Criança e do Adolescente), para estabelecer prioridade de tramitação aos processos de adoção em que o adotando for criança ou adolescente com deficiência ou com doença crônica. Diário Oficial da União, seção 1.

Mariano, F. N., \& Rossetti-Ferreira, M. C. (2008). Que perfil da família biológica e adotante, e da criança adotada revelam os processos judiciais? [What's the profile of the biological, adopting families and adopted child as revealed by the judicial processes?]. Psicologia: Reflexão e Crítica, 21(1), 11-19. doi:10.1590/S010279722008000100002

Martins, B. S., Fontes, F., Hespanha, P., \& Berg, A. (2012). A emancipação dos estudos da deficiência [The emancipation of disability studies]. Revista Crítica de Ciências Sociais, (98), 45-64. doi:10.4000/rccs.5014

Mello, A. G., \& Nuernberg, A. H. (2012). Gênero e deficiência: Interseções e perspectivas [Gender and disability: Intersections and perspectives]. Revista Estudos Feministas, 20(3), 635-655. doi:10.1590/S0104026X2012000300003

Minayo, M. C. S. (2009). O desafio da pesquisa social [The challenge of social research]. In M. C. S. Minayo (Org.), Pesquisa social: Teoria, método e criatividade [Social research: Theory, method and creativity] (28th ed., pp. 9-29). Petrópolis, RJ: Vozes.

Nunes, M. D. R., \& Dupas, G. (2011). Independence of children with Down syndrome: The experiences of families. Revista Latino-Americana de Enfermagem, 19(4), 985-933. doi:10.1590/S0104-11692011000400018

Oliveira, D. S., \& Schwartz, E. R. D. (2013). The new adoption law: Legal and psychological aspects. Estudos de Psicologia (Campinas), 30(3), 445-453. doi:10.1590/ S0103-166X2013000300014

Ortega, F. (2009). Deficiência, autismo e neurodiversidade [Disability, autism and neurodiversity]. Ciência \& Saúde Coletiva, 14(1), 67-77. doi:10.1590/S141381232009000100012

Otuka, L. K., Scorsolini-Comin, F., \& Santos, M. A. (2009). A configuração dos vínculos na adoção: Uma atualização no contexto Latino-Americano [The configuration of bonds in adoption: An update in the Latin-American context]. Revista Brasileira de Crescimento e Desenvolvimento Humano, 19(3), 475-486. Retrieved from http://pepsic. 
bvsalud.org/pdf/rbcdh/v19n3/13.pdf

Pereira, C. R., Torres, A. R. R., Falcão, L., \& Pereira, A. S. (2013). O papel de representações sociais sobre a natureza da homossexualidade na oposição ao casamento civil e à adoção por famílias homoafetivas [The role of social representations about the nature of homosexuality: Opposition to civil marriage and adoption by homoaffective families]. Psicologia: Teoria e Pesquisa, 29(1), 79-89. doi:10.1590/S0102-37722013000100010

Pontes, F. A. R., Silva, S. S. C., Garotti, M., \& Magalhães, C. M. C. (2007). Teoria do apego: Elementos para uma concepção sistêmica da vinculação humana [Attachment theory: Elements for a systematic conception of human bonding]. Aletheia, 26, 67-79. Retrieved from http:// pepsic.bvsalud.org/pdf/aletheia/n26/n26a07.pdf

Rosenthal, J. A. (1993). Outcomes of adoption of children with special needs. The Future of Children, 3(1), 77-88. Retrieved from http://futureofchildren.org/ futureofchildren/publications/docs/03_01_05.PDF

Rossetti-Ferreira, M. C., Almeida, I. G., Costa, N. R. A., Guimarães, L. A., Mariano, F. N., Teixeira, S. C. P., \& Serrano, S. A. (2012). Acolhimento de crianças e adolescentes em situações de abandono, violência e rupturas [Fostering children and adolescents in situations of abandonment, violence and separation]. Psicologia: Reflexão e Crítica, 25(2), 390-399. doi:10.1590/S010279722012000200021

Silva, M. L., \& Arpini, D. M. (2013). A nova lei nacional de adoção: Desafios para a reinserção familiar [New national adoption law: Challenges regarding family reinsertion]. Psicologia em Estudo, 18(1), 125-135. doi:10.1590/ S1413-73722013000100013

Silveira, A. M. (2005). Adoção de crianças negras: Inclusão ou exclusão? [Adoption of black children: Inclusion or exclusion?]. São Paulo, SP: Veras Editora.

Solomon, A. (2012). Far from the tree: Parents, children and the search for identity. New York, NY: Scribner.

Sousa, K. K., \& Paravidini, J. L. L. (2011). Vínculos entre crianças em situação de acolhimento institucional e visitantes da instituição [Bonds between sheltered children and visitors of host institutions]. Psicologia: Ciência e Profissão, 31(3), 536-553. doi:10.1590/S141498932011000300008

Gisele De Mozzi has a M.S. in Psychology from the Universidade Federal de Santa Catarina.

Adriano Henrique Nuernberg is an Associate Professor at the Universidade Federal de Santa Catarina.

Received: Feb. 12, 2015

1st Revision: June 4, 2015

2nd Revision: Sep. 4, 2015

Approved: Sep. 9, 2015

How to cite this article:

De Mozzi, G., \& Nuernberg, A. H. (2016). Adoption of children with disabilities: A study with adoptive parents. Paidéia (Ribeirão Preto), 26(63), 101-109. doi:10.1590/1982-43272663201612 